\title{
Prospects for Democratic Breakdown in the United States: Bringing the States Back In
}

\author{
Bernard Grofman
}

\begin{abstract}
The greatest threat of democratic breakdown stems from the federal structure of the US Constitution and from false claims of election fraud with the potential for state- or congressional- level reversals of popular vote outcomes. The potential for such a breakdown was revealed by the events of January 6, 2021, with tens of millions of voters still believing in the big lie and the repetition of that lie by legislators and government officials. It is exacerbated by hyperpolarization, minoritarian control caused by partisan gerrymandering for state legislative districts and in the US House, malapportionment in the US Senate, and the highest likelihood of Electoral College reversals of popular vote outcomes in more than a century. Democratic breakdown is also made more likely by recent legislation that makes it easier for legislators in some gerrymandered states to reverse the outcomes of the popular vote in their states.
\end{abstract}

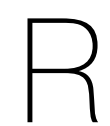
ecent work in political science, drawing on the comparative politics literature on features held in common by countries that have exhibited democratic breakdowns, and using tools such as qualitative classification analysis (QCA), have offered opposing points of view on whether the United States exhibits the features historically found to be associated with democratic breakdowns. I have great sympathy for the notion of seeing the United States as but one case among many (see, especially, Taylor et al. 2014, or Grofman 1999). Nor do I dispute the relevance of the two potentially causal factors highlighted by Weyland (2020)—an economic or other crisis and weakness in institutional supports for democratic decision making - although I also agree with a point made by Lopez and Luna (2021) that increased inequality and increased polarization should be taken into account. ${ }^{1}$ I do not attempt here

Bernard Grofman (1) is the Jack W. Peltason Chair of Democracy Studies and Distinguished Professor of Political Science at the University of California, Irvine (bgtravel@uci. edu). His research deals primarily with issues of representation, including minority voting rights and party competition. A fellow of the American Academy of Arts and Sciences, he has an honorary doctorate from the University of Copenhagen for his work on the study of elections. He is coauthor of five books with major university presses and coeditor of 26 other books and has written more than 200 research articles and book chapters. to resolve the differences between these two essays about either the general relevance of QCA analyses for the study of causality or the degree to which QCA findings support the claim that the United States displays many of the indicators whose combination could predict a high likelihood of democratic breakdown. Instead, I focus on institutional differences between the United States and other major democracies that suggest care in seeking to generalize from historical cross-national comparisons.

The United States differs from most other democracies in that it is a federal polity, and this is a factor neither Weyland (2020) nor Lopez and Luna (2021) incorporate into their models. If we think about the time path of US democracy and take as our slogan "Remember the Civil War" and recall, too, that the southern name for that war is the "War between the States," it is easy to see why the federal nature of the United States should be taken into account in any attempt to prognosticate democratic breakdown. Although I focus in this article on the implications of federalism - including factual aspects of party control at the legislative level and legal aspects of deference by federal courts to state-level authorities-I also discuss important changes in the structure of electoral competition in the United States, especially in terms of the increasingly minoritarian nature of major US political institutions, on the one hand, and the nature of mass beliefs about the integrity of the electoral process, on the other, that can substantially affect the prospects for democratic breakdown. permits unrestricted re-use, distribution and reproduction, provided the original article is properly cited. 
Before the January 6, 2021, certification vote in Congress of the 2020 presidential election and the continuing challenges to the legitimacy of reported presidential vote tallies in Arizona, Pennsylvania, and elsewhere, the possibility of democratic breakdown seemed remote. Yet the combination of the following factors makes nondemocratic outcomes easier to implement, more likely to happen, or both: (1) incredibly high levels of partisan polarization; (2) recent legislation passed by states under Republican trifecta control that makes partisan misreporting of ballot outcomes easier; (3) the high level of expected pro-Republican gerrymandering of state legislative and of congressional districts in the 2020 redistricting round that will make it much harder for Democrats to win majority control of many state legislatures or of Congress and that will insulate legislators from reprisals at the ballot box; (4) the high aggregate level of closeness in control of the House, the Senate, and the presidency, which makes each election result more consequential; and, perhaps most importantly, (5) the belief in the big lie that Biden is not the legitimate president, which is held not just by tens of millions of ordinary voters but also by a high proportion of Republican elected officials.

Although national-level partisan polarization and polarization along racial lines are obviously important, ${ }^{2}$ also of relevance is the degree to which polarization creates geographic divides, especially in terms of partisan control of the states, which has consequences for fair and free elections. Many election law specialists (see especially Hasen 2020) have warned about the potential for breakdown of the electoral process at the state level, not just at the federal level, and about state-level attempts to minimize the vote from disfavored groups.

The two most likely scenarios of democratic breakdown in the United States would be (1) when a Republicancontrolled legislature in a state with a Republican governor decides that a close congressional or presidential election in the state was "illegitimate" because of allegations of vote fraud committed by Democrats (almost certainly false but also almost impossible to disprove $)^{3}$ or (2) when a Republican-controlled US House or US Senate likewise challenges the certifications delivered by a state, as was unsuccessfully attempted on January 6, 2021. Such a legislative postelection reversal of the popular will, especially if it affected either the presidential outcome or control of Congress, could trigger a constitutional crisis of a form last seen in 1876. The resolution of the 1876 crisis was a compromise that ushered in nearly 100 years of Jim Crow suppression of minority rights. ${ }^{4} \mathrm{~A}$ similar resolution of a modern equivalent would not be an event to be cheered.

But we may ask, Aren't such scenarios highly implausible? I think not. First let us consider whether they could happen and then turn to how likely they are to happen.
Weyland (2020, 389) argues that our still intact system of checks and balances insulates the United States from breakdown because it prevents antidemocratic forces from capturing all the keys to the kingdom. In this context, it is useful, however, to be reminded just how successful President Trump was in eroding checks and balances. ${ }^{5}$ And let me emphasize two points: because of the federal nature of the US political system, antidemocratic forces can easily capture many states - and states have real legal power. Thus, even without a national victory for an autocrat, democracy could still be severely eroded. Reading the Federalist Papers, it is natural to think of the existence of local centers of power as a check on tyranny from the center, and the assertion that the states are "laboratories for democracy" reinforces a rosy picture. ${ }^{6}$ But even the most cursory study of the history of conflict over state's rights will reveal that federalism is not always a friend of democracy. And there are features of US federalism that can generate particular problems today.

First, unlike most countries, election administration in the United States is decentralized to the state level and often below that, such that counties count and certify votes. Second, malapportionment in the Senate is, by almost all measures, high relative to its historical average (Cervas and Grofman 2020); partisan gerrymandering in the House is at its highest level in the post-one person, one vote era (McGann et al. 2016; 2021; Wang 2013); and the distribution of electoral strength has made partisan bias in the Electoral College (EC) in the elections of 2016 and 2020 among the highest in recent history (Cervas and Grofman forthcoming). Moreover, rather than canceling each other out, each distortion is in a pro-Republican direction. For example, only a roughly $52 \%$ or higher popular vote for the Democratic candidate creates nearcertainty that the EC winner and the popular vote winner will be the same ${ }^{7}$; similarly, Democrats currently need more than $50 \%$ of the national two-party vote to capture either the House or the Senate. Such distortions can allow a minority of a state (or of the nation) to determine which party will be in power at the state or national level.

Third, and relatedly, when the Supreme Court in Rucho v. Common Cause 588 U.S._ (2019) rejected the view that federal courts had any role to play in placing a constitutional check on partisan gerrymandering, it in effect wrote a blank check to state legislatures by allowing them to engage in even more egregious gerrymandering in the 2020 redistricting round than they had in the 2010 round-which was already, as noted earlier, the most egregious in the post-Reynolds v. Sims history. Unlike in all other major democracies (Handley and Grofman 2008), electoral boundary drawing in most states is a partisan process, with a near-certainty of partisan gerrymandering when there is trifecta control of state government. 
Furthermore, the relative balance of Republican trifecta and Democratic trifecta states is unfavorable for Democrats going into the 2020 redistricting round. There are presently 15 Democratic and 23 Republican trifecta states, but that statistic is misleading because a number of these states are either single-seat states (where no redistricting is necessary) or they are states where a commission, rather than the legislature, is doing the redistricting. In terms of congressional redistricting, eliminating those states with commissions and excluding single-seat states, there are 7 states where Democrats are in full control and 19 where Republicans are in full control. But an even more relevant statistic for the potential for pro-Republican gerrymandering is that, excluding single-seat states, in 2020 Democrats fully controlled 72 seats in the House, whereas Republicans fully controlled $184 .{ }^{8}$ Moreover, the congressional seats that are being shifted after the 2020 censusbased apportionment are disproportionately in states whose legislatures are under Republican control.

Fourth, in some states with Republican trifecta control, such as Georgia, legislation has already been passed that would enable the state legislature to take over control of elections from local election boards and from the secretary of state; similar legislation is under consideration in other states. Such legislation is clearly intended by Trump supporters as a "muzzle the future Brad Raffenspergers" scheme. Although most of the public attention has been on the spate of legislation in many Republican-controlled legislatures that makes it harder to vote-at least as compared to very recent elections (see, e.g., Wines 2021) — the changes in ultimate administrative reporting authority are potentially far more consequential. ${ }^{9}$

Fifth, state legislatures already have the power to replace direct election by the voters of a slate of presidential electors committed to a given candidate with some other form of selection, although this change needs to be made sufficiently far in advance of the actual election (Anderson 2020a; 2020b). Under the US Constitution, how to select presidential electors is a matter for state discretion. ${ }^{10} \mathrm{In}$ particular, a state could decide to have the state legislature select presidential electors, as was the case in some states in the early period of US history. ${ }^{11}$ Gerrymandering of the state legislatures thus makes it quite possible that, in states that opted for this option, the result would be a partisan outcome opposite from that of the statewide popular vote.

Sixth, and more generally, Supreme Court precedents suggest strong deference to state election administration in the absence of clear constitutional violations. ${ }^{12}$ The strong pro-Republican bias at the state level, especially with respect to gerrymandered state legislatures, thus has important implications for outcomes in which the majority of voters are powerless to achieve their will. For example, if there is a challenge in federal courts to the decisions made by state legislatures (or governors) about which slate of electors to report in the case of dueling slates, or when legal challenges are unresolved in state courts or recounts are still underway after the "safe harbor" reporting deadline has passed, the legal issues can get murky and depend a lot on the exact details of state law, as well as on the stance of the legislature and the governor (Anderson, 2020a; 2020b). ${ }^{13}$ Moreover, Congress has the power to decide its own membership and has chosen between competing tallies reported from the same state, and it is hard to see the Supreme Court reversing congressional choices in the case of a congressional election, no matter how ill-founded these choices might be (see the discussion in Congressional Research Service 2021).

Of course, the fact that a gerrymandered state legislature or Congress could use a blatantly false excuse of ballot fraud (in elections won by a narrow margin) to substitute its will for the preferences of the voters, or that a state legislature could even do so directly in advance of any presidential election, does not mean that it would. And if you had asked me about the likelihood of such behaviors even as recently as a year ago, I would have pooh-poohed the idea. But there are four reasons why such behavior is today far more plausible.

First, incredibly high levels of partisan polarization, especially in the form of affective polarization, have caused some recent authors to view contemporary partisan competition as a new kind of "holy war" (Wuffle 2021). Arguably, in the aftermath of the 2020 election this polarization has only grown worse. To paraphrase Barry Goldwater, in a war against the forces of Satan, it is much easier to think that "extremism in the defense of one's way of life is no vice." In other words, the ends justify the means. Think of the 2021 decision by the Republicancontrolled Texas legislature to foster private citizens acting as bounty hunters to be paid $\$ 10,000$ to chase down anyone involved in aiding and abetting abortions, under the theory that private action is not state action and thus cannot easily be prevented by federal courts' enforcement of Roe v. Wade and the constitutionally protected rights of women. This is a clear instance of the unbelievable lengths to which state legislators are prepared to go to avoid federal oversight of their actions.

In the election context, the view that the ends justify the means is enhanced by righteous anger. Whether in the Capitol or the state house, a high proportion of Republican elected officials endorse the big lie that Biden is not the legitimate president. ${ }^{14}$ If you believe passionately that the 2020 election was stolen, then it may seem "only fair" to steal back elections from the other side in 2024 (or 2022).

Second, and most obviously, we have the events of January 6,2021 . Virtually all the news coverage of January 6 , especially coverage after that day, has focused on the storming of the Capitol and its implications for democratic breakdown. But, like the misdirection of a stage magician, worrying about the crowd initially outside the Capitol 
distracts attention from what was really important about January 6: the behavior of the Republican House members and senators inside the chamber. Having a hard core of white supremacists prepared to engage in violence and antigovernment behavior should come as no great shock, especially because they were emboldened by the president's speeches and tweets about a stolen election and the need for action; these pronouncements gave them a pretext, aided by the absence of sufficient police presence to be a real deterrent and being partially sheltered by having a crowd around them of people who were there because they truly thought that the election was stolen. ${ }^{15}$

In my view, what was truly shocking about January 6 was not the behavior of the demonstrators ${ }^{16}$ or even that of President Trump, which was more or less Trump being Trump, but the votes on accepting the tallies reported from two states that Trump had won in 2016 but had gone for Biden in 2020. In the case of Arizona, 6 Republican Senators and 121 Republican House members voted against accepting the result; the corresponding numbers for Pennsylvania were 7 and 138. In other words, in the US House, as many as $69 \%$ of the Republican members accepted the big lie that the election was stolen from Biden and were prepared to vote to reverse the "unacceptable" outcome. ${ }^{17}$ Votes were held on only two states because each had a challenge to results from both a senator and member of the House from that state, which is required to force a congressional vote. But the percentage of votes objecting to Arizona and Pennsylvania results would almost certainly have been similar had Georgia, Michigan, Nevada, and Wisconsin-the four other states to whose results at least one Republican member of Congress had lodged an objection-also come up for a vote before the Capitol was evacuated due to the insurrection. No matter how pernicious and even deadly was the storming of the Capitol building, its repercussions or those of similar acts can be dealt with through the channels of ordinary governance; that is, through arrests and convictions for unlawful actions. The same is not nearly as true for illegitimate actions by state officials when these actions can be given the color of law.

Third, pragmatic considerations of office-seeking/office retention are of limited relevance. Most Republican state legislators and most Republican members of Congress occupy districts that are highly insulated from electoral challenge by a Democrat.

Fourth, the high aggregate level of closeness in control of the House, Senate, and the presidency raises the stakes for each and every congressional election and outcomes at the state level for president and senators (Fiorina 2017; Lee 2016). ${ }^{18}$ The higher the stakes, the higher the incentives to cheat, especially if you think that, because you have control of the key organs of government in your state or in Congress, you can get away with it.
In 2020, President Trump encouraged Republican governors and legislatures to override the popular vote outcome in close states that he lost. In 2020 they disregarded him. In 2020 President Trump urged (ordered?) the Republican vice president presiding over the Senate to disregard the results of reported outcomes in close states won by Joe Biden. He did not comply. What will happen in 2024 is far less certain, because moderates within the Republican Party are being purged in favor of Trump loyalists and a clear majority of Trump supporters still believe in the lie of a stolen election, despite all the evidence to the contrary.

Views about the resilience of US democracy need to be tempered by analysis of how what is happening at the state level can affect national-level politics. Yet the degree of belief in Trump's big lie about his election loss in 2020 can only serve to exacerbate previous fault lines in American politics, ${ }^{19}$ much the same way that economic shocks, such as extraordinary high levels of unemployment ${ }^{20}$ or runaway inflation, or defeat in war in a way that staggers national confidence have been argued to help trigger democratic breakdowns in Europe or elsewhere.

The reader may object to a seeming lack of evenhandedness in this focus on the likelihood of a democratic breakdown coming from the Republican side of the aisle, because certainly Democrats in the past have also been accused of stealing elections ${ }^{21}$ and there has been violence on the part of some Black Lives Matter supporters. But it is Republicans who have embraced the big lie of a stolen presidential election, which is one of the driving forces that could trigger a democratic breakdown today.

Yet, a democratic breakdown is not inevitable. Consider one possible scenario that leads to a democratic breakdown:

1. If a state legislature takes over from a county election administration (as the legislature gave itself the direct power to do in Georgia this June), and

2. if the legislature or governor brings in a totally unqualified and highly partisan firm to do a recount (as the Arizona legislature did), and

3. if the recount reversed the original result in which a Democrat was elected, and

4. if the legislature decided that this recount was to become the official result, and

5. if the state's highest court decided that this was a purely political question that needed to be left to the legislature and governor, and

6. if the Supreme Court, on legal challenge, buried its head in the sand regarding political reality (as legal scholars such as Stephanopoulos [2019] and Hasen [2021] have argued it is now wont to do) and said that this was entirely a matter of state election administration and that the state decision did not raise federal constitutional questions that mandated a reversal of the state's reported election outcome, 
then, if such a sequence of events were to occur, it is hard to argue that this would not be a democratic breakdown. For such a scenario, this article has identified the pivot points that would allow this breakdown to happen.

In thinking about this scenario, however, it is important to remember the Anna Karenina principle. ${ }^{22}$ That principle states that, in any endeavor that rests on a sequence of necessary conditions, the failure of any one of these conditions dooms it to failure. So, if any YES on this "if sequence ladder" is actually a $\mathrm{NO}$, then somewhere down the ladder, a breakdown involving an illegitimate reversal of an election outcome will be averted.

On the other hand, almost any YES on this "if sequence ladder" is a point of democratic vulnerability, and some might even be regarded as democratic breakdowns in and of themselves, even if the winner of an election is eventually legally acknowledged as such. Moreover, cliffhangers are only fun if you are at the beach on a blanket in the sand reading a mystery thriller; they are not at all fun when the consequences of falling off the cliff are real, especially if you are worrying that you might be an ostrich burying your head in the sand about the true magnitude of the threat.

\section{Acknowledgement}

My work on this article was supported by funding from the Peltason Chair of Democracy Studies at UC Irvine (UCI). I am indebted to my many colleagues for helpful conversations over the years about elections and the role of federalism in American politics, with special thanks to Arend Lijphart, Matt Shugart, Steven Taylor, Sam Wang, and Keena Lipsitz-and with particular thanks to Jonathan Cervas for his thoughtful discussions of an earlier version of this article and his encouragement to write it. I also would like to thank two anonymous reviewers, with special thanks to the reviewer who gave me the challenge of explaining more clearly how we would know which factors were responsible for a democratic breakdown and which might have prevented one. However, the single author to whom I am most indebted is my UCI Law School colleague, Rick Hasen, many of whose insights into election law are reflected here. Of course, errors remaining are solely my responsibility.

\section{Notes}

1 The literature on polarization is too vast to do it justice. For one useful pre-Trump overview, see Pildes (2011).

2 See, for example, Hinton (2021) for a frightening portrait of the potential for racial conflict led by white racists.

3 Based on what happened in 2020, such allegations might also be accompanied by the claim that fraud was centered in the most heavily minority areas of the states.
4 The last time we had two different slates of electors from a state was in the 1960 election. After Hawaiian state courts finished adjudicating the dispute, having ordered a variety of specific recounts that were in agreement with the final recount, the Republican governor certified the electors for Democrat John F. Kennedy. Congress unanimously chose to count that slate's votes for Kennedy. Richard Nixon, the presiding officer in the Senate, did not object (see Anderson 2020a). I pose as a question to readers: "Would all Republican Governors behave the same way today?"

5 In particular, President Trump neutered (or turned into a cheerleader) the US attorney general (compare the behavior of the attorney general in the 1973 "Saturday Night Massacre" when Nixon was president), and the fear he engendered among Republican officeholders in Congress made all but a handful of them pusillanimous when it came to criticizing acts such as threatening a foreign official with reduction in US support to his country if he failed to investigate the son of President Trump's most likely 2020 Democratic opponent, or using the presidency to enrich his family coffers by steering business to Trump-owned properties, or demanding that a Georgia state official "find" more votes for him in the 2020 election in the state, or dilly-dallying with his response while the Capitol was being invaded by baseball-bat-carrying protestors and legislators were being driven to seek hiding. President Trump, also installed close allies at other critical levers of power, including the CIA, the FBI, and the Defense Department. According to some sources, the president's behavior before the 2020 election caused the head of the Joint Chiefs of Staff, General Mark A. Milley, to seriously worry whether Trump was planning a coup if he lost and had the general thinking about how to forestall such an event (Thebault 2021).

6 "Laboratories of democracy" is a phrase popularized by US Supreme Court Justice Louis Brandeis in New State Ice Co. v. Liebmann 285 U.S. 262 (1932), which continues to be cited (see Andrews 2015).

7 Thus, in terms of potential democratic breakdowns, if 2024 generated the same Electoral College reversal of the popular vote as we had in 2000 and 2016, then the legitimacy of the election process becomes a targetbut this time the attack is almost certain to come from the liberal direction. That is because, given the present-day distribution of partisan electoral strength, the likelihood of a EC reversal of popular vote outcome is far more likely to occur in a direction that benefits the Republican candidate than in a direction that benefits the Democratic candidate (Cervas and Grofman 2021; forthcoming).

8 Although Republicans had an even greater advantage in 2010 than they have in 2020 vis-à-vis congressional 
line drawing (in 2010, Democrats fully controlled the congressional districting process in 44 seats, whereas Republicans fully controlled 205 House seats), lingering effects of past gerrymandering in what is universally agreed was the decade with the most egregious partisan gerrymanders will help assure Republican control of states even when districts are redrawn by courts or commissions in 2021-22. Courts drawing new plans in situations of legislative deadlock, or even when there is a finding of a constitutional violation, seek to avoid the pairing (or displacement) of incumbents, and incumbents in state legislatures are presently disproportionately Republicans in most of the commission or divided states.

9 In Georgia, for example, the recently passed legislation strips authority from the secretary of state, making that official a nonvoting member of the State Elections Board, and allows lawmakers to initiate takeovers of local election boards (Gardner and Wang 2021). The reader will recall that Raffensperger, Georgia's secretary of state in 2020 and a Republican, was one of the election officials whom Trump vilified, especially after Raffensperger rejected Trump's phone plea for him to "find" more votes for Trump and went public with the call. Today, the administration of the US election process is largely in the hands of local officials with clear partisan identities, but remarkably, those officials have also shown remarkable loyalty to the notion of impartiality and honest counting. The same cannot be said for the Republican state legislators in Georgia who passed the new legislation, virtually all of whom have bought into Trump's myth of massive electoral fraud in 2020. I would also note that, in North Carolina, "existing state laws authorize its General Assembly to appoint [presidential] electors if disputes are still outstanding by the date the safe harbor window closes. If the General Assembly does not act by the day that electors are required to vote, North Carolina's governor may step in and appoint electors. Both are obligated to appoint electors based on 'their best judgment of the will of the electorate" (Anderson 2020a).

10 U.S. Constitution, Article, II, Section I: Each State shall appoint, in such manner as the Legislature thereof may direct, a number of Electors."

11 Wuffle (2021) referred to such a removal of direct popular sovereignty over the presidential outcomes in a state as the "nuclear option."

12 Recent court cases in the voting rights domain reinforce the view that the present Supreme Court is reluctant to tamper with election administration decisions by the states so long as they are racially and politically neutral on their face and cannot be shown to have been enacted with a discriminatory purpose (see, e.g., Brnovich v. Democratic National Committee [2021]).
13 In Bush v. Gore 531 U.S. 98 (2000), the Supreme Court in 2000 found statutory support for a "safe harbor" deadline for reporting the presidential vote to Congress and found unconstitutional the differences in Florida in standards at the county level for interpreting the will of the voter from ballot features such as "hanging chads." But that ruling was explicitly limited to apply only to the specific case facts in Florida in 2000.

14 Recall, for example, the 18 Republican State Attorneys General who endorsed the big lie in a lawsuit in federal court to overturn the 2020 election (Lucas 2020).

15 Liberal readers might ask themselves this question: "If I sincerely believed that the 2016 election had been characterized by massive fraud committed by Republicans, and that was the only reason Donald Trump-who is anathema to just about everything I believe in-was president, would I have wanted to march on the Capitol?” The coming years will pit many people who have been duped and want to fight for a democracy that they sincerely think has been stolen from them against equally sincere people who are smart enough not to believe the big lie and who want to protect democracy against the liars. The truly unfortunate fact is the number of Republican elected officials who know the truth but maintain the lie because they place a higher importance on preserving their career, keeping the Democrats from power, or both.

16 Some groups came to the mall equipped with baseball bats and partial armor. See "Days of Rage: An InDepth Look at How a Mob Stormed the Capitol," a July 2021 New York Times video report on the riot using footage collected from many sources, including some filmed by the rioters themselves.

17 Although I believe that this proportion would have been even higher had the Republicans held a majority in the House, a counterargument is that Republicans could safely express their loyalty to Trump by voting to reject outcomes in Pennsylvania and Arizona in full confidence that their votes would be irrelevant. If their vote really had determined who was going to be the next president, Republican objectors might have been less willing to sacrifice principle to party.

18 In addition, a change in filibustering rules as they affect Supreme Court appointments, allowing one party to control judicial appointments without input from the other party, operates to raise still further the stakes of partisan control of Congress and the presidency.

19 The legacy of Trump's lie will long outlive him, and it is hard to see how to persuade those who believe in the lie that it is a lie. For example, as a recent op-ed in the New York Times (Astor 2021) noted, the wrong results initially reported by the election board in the 2021 
New York City mayoral race that were due to a computer error (failing to purge trial results testing the algorithm for computing winners in rank-choice voting elections) can only inflame conspiracy theories about 2020 — even though the computer errors were quickly acknowledged and then readily corrected. A Republican presidential loss in 2024 would probably only deepen the anger of Trump's most loyal supporters.

20 In this context it is useful to remember that the possibility of Democratic breakdown in the United States in the 1930s was very real. In the 1935 novel by Sinclair Lewis, It Can't Happen Here, he outlines a scenario for a fascist takeover that reads chillingly prescient today. Consider this key line from that novel: "When fascism comes to America it will be wrapped in the flag and carrying a cross."

21 For example, Stacey Abrams, a Democrat, asserted that the Georgia governorship was stolen from her by a corrupt Republican secretary of state (Lee 2020). That secretary administered an election in which he was also on the ballot.

22 The name of the principle derives from Leo Tolstoy's 1877 novel Anna Karenina, which begins, "All happy families are alike; each unhappy family is unhappy in its own way" (https://en.wikipedia.org/ wiki/Anna_Karenina_principle, accessed June $7,2021)$. The idea behind the naming of this principle is that the absence of any single factor or set of factors necessary for happiness can lead to unhappiness, so that there will many different routes to unhappiness.

\section{References}

Anderson, Scott R. 2020a. "How to Resolve a Contested Election, Part 1: The States and their Electors."

Lawfare, October 20. https://www.lawfareblog.com/ how-resolve-contested-election-part-1-states-and-theirelectors.

Anderson, Scott R. 2020b. "How to Resolve a Contested Election, Part 2: How Congress Counts the Electoral Votes." Lawfare, October 22. https:// www.lawfareblog.com/how-resolve-contested-electionpart-2-how-congress-counts-electoral-vote.

Andrews, Edmund. 2015. "Steven Callander: How to Make States 'Laboratories of Democracy." Insights. Graduate School of Business, Stanford University, May 19. https://www.gsb.stanford.edu/insights/stevencallander-how-make-states-laboratories-democracy.

Astor, Maggie. "Why New York's Election Debacle Is Likely to Fuel Conspiracy Theories." New York Times, July 6, 2021.

Cervas, Jonathan R., and Bernard Grofman. 2020. "Legal, Political Science and Economics Approaches to Measuring Malapportionment: The U.S. House, the Senate and the Electoral College 1790-2010." Social Sciences Quarterly 101(6): 2238-256.
_ 2021. "Is the Electoral College Biased against Democrats: An Historical and Analytic Perspective." Unpublished manuscript, August.

- forthcoming. "Communication: Partisan Bias in the Electoral College in 2020 Compared to Other Recent Presidential Elections.” Political Geography.

Congressional Research Service. 2021. "The Federal Contested Elections Act: Overview and Recent Contests in the House of Representatives" CRC in Focus, January 19.

Fiorina, Morris P. 2017. Unstable Majorities: Polarization, Party Sorting, and Political Stalemate. Stanford: Hoover Institution Press.

Gardner, Amy, and Amy B. Wang. 2021. "Georgia Governor Signs into Law Sweeping Voting Bill that Curtails the Use of Drop Boxes and Imposes New ID Requirements for Mail Voting." Washington Post, March 25.

Grofman, Bernard. 1999. "Introduction." In Elections in Japan, Korea, and Taiwan under the Single NonTransferable Vote: The Comparative Study of an Embedded Institution, eds. Bernard Grofman, SungChull Lee, Edwin Winckler, and Brian Woodall. Ann Arbor: University of Michigan Press, 1-14.

Handley, Lisa and Bernard Grofman, eds. 2008. Redistricting in Comparative Perspective. Oxford: Oxford University Press.

Hasen, Rick. 2020. Election Meltdown: Dirty Tricks, Distrust, and the Threat to American Democracy. New Haven: Yale University Press.

Hasen, Rick. 2021. "The Supreme Court's Pro-Partisanship Turn." Georgetown Law Review 109: 50-80.

Hinton, Alexander Laban. 2021. It Can Happen Here: White Power and the Rising Threat of Genocide in the U.S. New York: New York University Press.

Lee, Ella. 2020. "Fact Check: Post Online about Stacey Abrams' 2018 Run for Georgia Governor Is Partly False." USA Today, November 18.

Lee, Frances E. 2016. Insecure Majorities: Congress and the Perpetual Campaign. Chicago: University of Chicago Press.

Lewis, Sinclair. 1935. It Can't Happen Here. New York: Penguin Books.

López, Matias, and Juan Pablo Luna. 2021. "Assessing the Risk of Democratic Reversal in the United States: A Reply to Kurt Weyland." PS: Political Science and Politics (July): 421-26.

Lucas, Scott. 2020. “'Seditious Abuse': 18 State Attorneys General, 106 GOP House Members Try to Overturn Election. EA World View, December 11.

McGann, Anthony J., Charles A. Smith, Michael Latner, and Alex Keena. 2016. Gerrymandering in America: The House of Representatives, The Supreme Court, and the Future of Popular Sovereignty. New York: Cambridge University Press. 
McGann, Anthony J., Charles A. Smith, Michael Latner, and Alex Keena. 2021. Gerrymandering the States: Partisanship, Race, and the Transformation of American Federalism. New York: Cambridge University Press

New York Times. 2021 "Days of Rage: An In-Depth Look at How a Mob Stormed the Capitol.” July 12, 2021.

Pildes, Richard H. 2011. "Why the Center Does Not Hold: The Causes of Hyperpolarized Democracy in America." California Law Review 99 (2): 273-333.

Stephanopoulos, Nicholas. 2019. "The Anti-Carolene Court." Supreme Court Review 111: 178.

Taylor, Steven, Matthew Shugart, Arend Lijphart, and Bernard Grofman. 2014. A Different Democracy: American Government in a Thirty-One Country Perspective. New Haven: Yale University Press.
Thebault, Reis. 2021. "Joint Chiefs Chairman Feared Potential 'Reichstag Moment' Aimed at Keeping Trump in Power." Washington Post, July 14 .

Wang, S. S. H. 2013. "The Great Gerrymander of 2012.” New York Times, February 2.

Weyland, Kurt. 2020. "Populism's Threat to Democracy: Comparative Lessons for the United States." Perspectives on Politics 18 (2): 389-406.

Wines, Michael. 2021. "In Statehouses, Stolen-Election Myth Fuels a G.O.P. Drive to Rewrite Rules." New York Times, February 27.

Wuffle, A. 2021. "Some Insights into Electoral Campaigning in the Era of Trump and Beyond." PS: Political Science and Politics 54 (3): 462-66. 